\title{
Does High-Density Lipoprotein Have a Role in Dysregulated Host Response in Sepsis?
}

\section{Sepsisteki Disregüle Konak Yanıtında HDL'nin Rolü Var Mı?}

\author{
(D) Sinan Aşar1, (1) Mehmet Süleyman Sabaz², (D) Evrim Kucur Tülübaş¹, (1) Özlem Acicbe³, (1) Zafer Çukurova ${ }^{1}$ \\ ${ }^{1}$ University of Health Sciences Turkey, Bakırköy Dr. Sadi Konuk Training and Research Hospital, Clinic of Anesthesiology and Reanimation, İstanbul, \\ Turkey \\ ${ }^{2}$ Marmara University Pendik Training and Research Hospital, Clinic of Anesthesiology and Reanimation, Division of Intensive Care, İstanbul, Turkey \\ ${ }^{3}$ University of Health Sciences Turkey, Şişli Hamidiye Etfal Training and Research Hospital, Clinic of Intensive Care, İstanbul, Turkey
}

\begin{abstract}
Objective: Serum lipoprotein levels [high-density lipoprotein (HDL), low-density lipoprotein (LDL)], total cholesterol, and triglyceride) have protective functions against sepsis. Reduced levels are associated with organ dysfunction and mortality. This retrospective cohort study aimed to investigate the relationship between the serum lipoprotein levels and sepsis in a large population of patients admitted in the intensive care unit. Methods: Serum lipoprotein levels of 151 patients diagnosed with sepsis and 450 without sepsis were analyzed retrospectively. The level of lipoprotein decreased in the sepsis and non-sepsis groups, and appropriate statistical methods were used.

Results: Lipoprotein levels were significantly lower in the sepsis group $(p<0.05)$. No significant difference was found between the survivor group and non-survivor group in terms of lipoprotein levels $(p>0.05)$. Among patients with intra-abdominal sepsis and pneumosepsis, a significant difference was found in the levels of $\mathrm{HDL}, \mathrm{LDL}$, and total cholesterol between patients admitted in the medical and surgical intensive care units $(p<0.05)$. HDL levels were lower in patients with gram-negative bacterial infection than those with gram-positive bacterial infection.

Conclusion: This study provides evidence of the role of serum lipoproteins, particularly HDL, in the pathogenesis of sepsis, suggesting that lipoproteins may offer new avenue in the treatment of sepsis.
\end{abstract}

Keywords: Sepsis, lipoprotein, albumin effect, HDL

\section{öz}

Amaç: Serum lipoprotein düzeylerinin [yüksek yoğunluklu lipoprotein (HDL) ve düşük yoğunluklu lipoprotein (LDL)] total kolesterol ve trigliserid sepsise karşı koruyucu fonksiyonu vardır. Azalmış düzeyler, organ disfonksiyonu ve mortalite ile ilişkilidir. Bu retrospektif kohort çalışmasının amacı, geniş bir yoğun bakım hasta popülasyonunda sepsis ve serum lipoprotein düzeyleri arasındaki ilişkiyi araştırmaktır.

Gereç ve Yöntem: Sepsis tanısı konan 151 hasta ve 450 sepsis olmayan hastanın serum lipoprotein düzeyleri retrospektif olarak analiz edildi. Sepsis ve sepsis olmayan hastalarda lipoprotein düzeyleri karşılaştırıldı.

Bulgular: Lipoprotein düzeylerinin sepsis hastalarında daha düşük olduğu belirlendi $(p<0,05)$. Hayatta kalan ve mortalite gelişen hastalar arasında lipoprotein düzeyleri açısından anlamlı fark yoktu $(p>0,05)$. İntraabdominal sepsis ve pnömosepsis nedeniyle takip edilen medikal ve cerrahi yoğun bakım hastalarında HDL, LDL ve total kolesterol düzeyleri anlamlı farklılık gösterdi $(p<0,05)$. Gram-negatif bakteriyel enfeksiyonu olan hastalarda, gram-pozitif enfeksiyonu olanlara göre HDL düzeyleri daha düşük bulundu.

Sonuç: Bu çalışmanın bulguları serum lipoproteinlerinin ve özellikle HDL'nin sepsis patogenezindeki rolü hakkında yeni kanıtlar sunmakta, sepsis tedavisinde lipoproteinlerin yeni bir yol açabileceğini göstermektedir.

Anahtar Kelimeler: Sepsis, lipoprotein, albümin efekt, HDL

Address for Correspondence: Sinan Aşar, University of Health Sciences Turkey, Bakırköy Dr. Sadi Konuk Training and Research Hospital, Clinic of Anesthesiology and Reanimation, Istanbul, Turkey

Phone: +90 5442659844 E-mail: sinan.asaras@gmail.com ORCID ID: orcid.org/0000-0001-5787-5885

Cite as: Aşar S, Sabaz MS, Kuçur Tülübaş E, Acicbe Ö, Çukurova Z. Does High-Density Lipoprotein Have a Role in Dysregulated Host Response in Sepsis? Med J Bakirkoy 2021;17:214-220 


\section{INTRODUCTION}

Sepsis is a life-threatening organ dysfunction-associated syndrome that results from a dysregulated host response to infection. Sepsis is a global problem with high morbidity and mortality rates. The mortality rate of sepsis range from $17 \%$ to $26 \%$, and this may increase in middle- and lowincome countries (1).

Lipopolysaccharide (LPS, gram-negative) and lipoteichoic acid (gram-positive) are known endotoxins, lipophilic, and bacterial cell wall components responsible for bacterial virulence. LPS initiates the release of cytokines. It results in intravascular coagulopathy, hypotension, multiple organ failure, and ultimately death if these progress to uncontrolled inflammatory response. These are the clinical signs and symptoms of sepsis and septic shock (2).

Numerous studies have shown that lipoproteins can bind and neutralize gram-negative and gram-positive bacterial toxins, which serves as the so-called pathogen lipid sink (3).

High-density lipoprotein cholesterol (HDL-C) neutralizes LPS and gram-positive lipoteichoic acid and mediates toxin clearance (4-6). Changes in HDL-C function occur during sepsis. This dysfunctional and pro-inflammatory form of $\mathrm{HDL}$ was shown to predict organ failure (7). Decreased levels of HDL-C were associated with mortality in sepsis $(8,9)$. Lowdensity lipoprotein cholesterol (LDL-C) can also bind LPS and lipoteichoic acid and facilitate bacterial toxin clearance $(4,5)$. Decreased levels of LDL-C can predict organ failure and mortality in patients with sepsis (10).

In a long-term observational study investigating the association of lipid and lipoprotein levels with clinical benefit, low cholesterol levels were found to be associated with increased mortality, while the Kaiser Permanente study of 15,000 healthy individuals revealed that it was associated with the development of infectious diseases $(11,12)$. Hypolipidemia was associated with an increased risk of infection and poor clinical outcomes in patients with critical conditions $(13,14)$.

This study aimed to investigate the relationship between serum lipoprotein levels and sepsis in a large population of patients admitted in the intensive care unit (ICU).

\section{METHODS}

\section{Patients (Obtaining Patient Data)}

This study was approved by the Clinical Research Ethics Committee of the public Bakırköy Dr. Sadi Konuk Training and Research Hospital where the study was conducted (dated: 14.10.2019 and no: 2019/459). Data of 8.738 patients in the registry of "ImdSoft-Metavision/QlinICU Clinical Decision Support Software (Canada)," who were hospitalized between January 01, 2013, and August 19, 2019, in the general ICU of the anesthesia and reanimation clinic of this hospital were obtained using Structured Query Language queries. The levels of HDL-C, LDL-C, total cholesterol, and triglyceride were available in 1.372 of these patients on the first admission to the ICU. A total of 151 patients with sepsis and calculated serum lipoprotein levels, as well as procalcitonin, white blood cell, C-reactive protein (CRP), lactate, blood gas, and biochemical parameters (sepsis group) and 450 patients without sepsis (non-sepsis group) who met the same conditions, were included in the study. Blood gas samples were checked with the ABL800 (Radiometer, Denmark, Copenhagen) device. Biochemical tests were performed with the AU5800 biochemistry autoanalyzer (Beckman Coulter, Inc., Brea, CA, USA). The mean systolic, diastolic, and mean arterial pressures measured noninvasively at 5-min intervals during the ICU stay as well as the total balance, which is the total input-total output difference during the ICU stay, were calculated using appropriate software.

Urine, sputum, endotracheal aspirate, wound site, and intracatheter and peripheral blood culture data collected from patients with infection foci were recorded. Blood cultures were maintained in the BACTEC 9000 MB automation system (Becton Dickinson, USA) for 7 days if there was no bacterial reproduction. Necessary pretreatments were performed in the reproductive cultures, and identification and antibiotic susceptibility of microorganisms were determined in the VITEC $2 \circledast$ system (bioMerieux, France).

Patients with liver cirrhosis, renal failure receiving dialysis treatment, and end-stage chronic obstructive pulmonary disease and who did not stay in the ICU for more than $24 \mathrm{~h}$ were not included in the study. Moreover, patients whose initial and final age, Acute Physiology and Chronic Health Evaluation (APACHE II-IV) score, Simplified Acute Physiology score 3 (SAPS3) score, and Sequential Organ Failure Assessment (SOFA) score were not calculated in the software were not included in the study.

\section{Diagnosis of Sepsis}

Patients who previously had sepsis-2 and sepsis-3 septic shock events defined according to the sepsis 2012 (15) and sepsis 2016 guidelines (16) were included in the analysis (supplementary data) based on the following criteria:

1) Patients with bacterial growth in one of the two blood cultures because of suspected infection or bacterial growth 
in two of the four blood cultures in the presence of a central catheter (two vials) according to the medical histories, clinical examinations, and laboratory and radiological findings.

2) Patients with bacterial growth more than $100,000 \mathrm{cfu} /$ ml'in one of the urine, tracheal, body fluid, wound swab samples, and catheter cultures.

3) Patients without bacterial growth in the blood culture, who met the sepsis and septic shock diagnosis criteria according to the sepsis 2016 guideline (2):

a) Fever $>38.0{ }^{\circ} \mathrm{C}$, b) $\mathrm{CRP}>0.02 \mathrm{mcg} / \mathrm{L}$, c) $10,000<$ leukocytosis $<4,00010 \mathrm{e} / \mathrm{UL}$, d) neutrophil $>\% 80$, e) ICU admission SOFA $>2$ or patients with high SOFA score calculated after the admission value indicated sepsis (supplementary data).

\section{Septic Shock Diagnosis}

Despite adequate fluid rescucitation, $M A P<65 \mathrm{mmHg}$ and lactate $>2.5 \mathrm{mmol}$, requiring at least one intravenous vasopressor medication to maintain MAP> $65 \mathrm{mmHg}$.

\section{Statistical Analysis}

The GraphPad Prism (v 5.01) program was used for the statistical analysis of data obtained in the study. Frequency distribution and percentages of qualitative variables such as gender were calculated, and the chi-square test was used to determine significant differences. After determining the homogeneity of the variables by using the ShapiroWilk normality test, Student's t-test was used to compare independent and homogeneous binary variables, and the Mann-Whitney U test was used to compare non-homogeneous
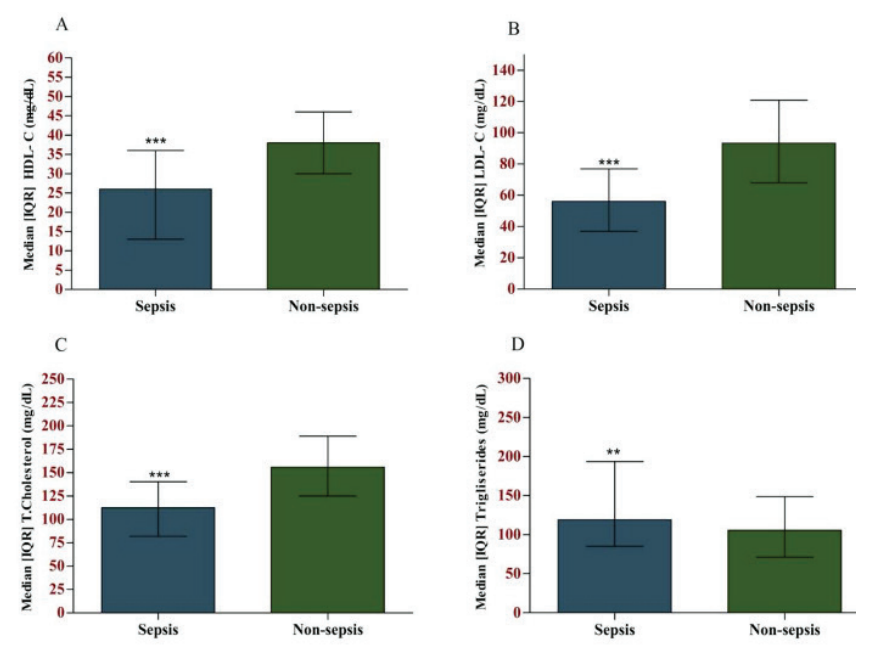

Figure 1. In the Mann-Whitney $U$ test analyses of different blood serum lipoproteins of patients with and without sepsis. (A) Highdensity lipoprotein cholesterol. (B) Low-density lipoprotein cholesterol. (C) Total cholesterol. (D) Triglycerides ${ }^{\star *} \mathrm{p}<0.01,{ }^{\star * \star} \mathrm{p}<0.001$ binary variables. The Spearman correlation test was used to analyze the correlation of data. Chi-square test was used to compare variables according to gender. The log-rank (MantelCox) test and Gehan-Breslow-Wilcoxon test were used to determine significant differences in the intergroup survival analyses in terms of survival percentages, median survival, median ratio, and $95 \%$ confidence interval $(\mathrm{Cl})$. The median interquartile range (IQR) values were taken as the reference. Values of $p<0.05$ were considered significant. For the graphical representation, $p$-values are summarized as follows: ${ }^{*} p<0.05$, ${ }^{* \star} p<0.01,{ }^{* * *} p<0.001, p \geq 0.05=$ not significant (ns).

\section{RESULTS}

In this study, serum lipoprotein levels (HDL-C, LDL-C, total cholesterol, and triglyceride) on ICU admission of patients with sepsis $(n=151)$ and without sepsis $(n=450)$ were compared retrospectively (Figure 1).

When the ICU admission HDL-C, LDL-C, total cholesterol, and triglyceride values of the sepsis group $(n=151)$ and non-sepsis group ( $n=451$ ) were compared using the MannWhitney $U$ test, the median and IQR values were 26 (13$36)$ and 38 (30-46) $\mathrm{mg} / \mathrm{dL}$, respectively, for the HDL-C. The median and IQR values were 56 (36-76) and 93 (68-120) mg/ $\mathrm{dL}$, respectively, for the LDL-C, and those for total cholesterol were 112 (82-140) and $156(125-189) \mathrm{mg} / \mathrm{dL}$, respectively. Differences among HDL-C, LDL-C, and total cholesterol values were significant (Figure $1 A, B, C, p<0.0001$ ). The median and IQR values for triglycerides were 119 (85-193) and 105 (71-148) mg/dL, and the difference was significant (Figure 1D, $\mathrm{p}=0.002$ ).

The age values of the sepsis and non-sepsis groups were compared using Student's t-test. The initial and final values of the height, body weight, body mass index, length of ICU stay, invasive mechanical ventilation time, APACHE II score, APACHE IV score, SOFA score, and biochemical parameters were compared with the Mann-Whitney $U$ test, and the median, IQR values, and $p$ values are shown in Table 1 . Categorical variables such as gender were compared with the chi-square test, and the frequency, percentage, and $p$ values are shown in Table 1. Patients with sepsis were divided into the surgical and medical subgroups of intraabdominal sepsis and pneumosepsis. However, the grampositive and gram-negative subgroups were established as having culture-positive and culture-negative results, and the parameters were compared in binary using the MannWhitney $U$ test. The sepsis and non-sepsis groups were analyzed in terms of survival according to their duration of ICU stay (day) (Table 1).

In the comparison of patients with intra-abdominal sepsis $(33 \%, n=49)$ and pneumosepsis $(46 \%, n=69)$, the median and 
Aşar et al. HDL's Role in Sepsis

Table 1. Characteristics of patients with and without sepsis

\begin{tabular}{|c|c|c|c|}
\hline Patient characteristics & Sepsis $(n=151)$ & Non-sepsis $(n=450)$ & $\mathrm{p}$ \\
\hline Gender, female, no (\%) & $54(35 \%)$ & $215(48 \%)$ & $0.018^{*}$ \\
\hline Age (year) & $59.6 \pm 19.6$ & $60.8 \pm 19.5$ & 0.4976 \\
\hline Height, median (IOR 25-75) (m) & $1.65(1.6-1.735)$ & $1.67(1.6-1.75)$ & 0.2909 \\
\hline Tracheostomy time, median (IQR) (hour) & $290.2(69.11-604.8)$ & $265.4(137.7-411)$ & 0.1657 \\
\hline Body weight, median (IQR) (kg) & $75(60-85)$ & $75(65-85)$ & 0.628 \\
\hline Body mass index, median (IQR) $\left(\mathrm{kg} / \mathrm{m}^{2}\right)$ & $25.39(22.49-27.85)$ & $26.12(24.22-29.14)$ & 0.0537 \\
\hline Length of stay in the ICU, median (IQR) (day) & $5(3-15)$ & $2(1-4)$ & $<0.0001^{\star \star \star}$ \\
\hline Invasive MV time, median (IQR) (hour) & $138.2(79.73-396.6)$ & $94.33(38.74-211.7)$ & $0.0019 * \star$ \\
\hline SOFA score first, median (IQR) & $8(4-11)$ & $4(2-6)$ & $<0.0001^{\star \star \star}$ \\
\hline SOFA score last, median (IQR) & $8(4-12.25)$ & $3(1-5)$ & $<0.0001^{\star \star \star}$ \\
\hline APACHE II score first, median (IQR) & $20.5(14-24)$ & $14(9-20)$ & $<0.0001^{\star \star \star}$ \\
\hline APACHE II score last, median (IQR) & $18(12-23)$ & $13(9-19)$ & $<0.0001^{\star \star \star}$ \\
\hline APACHE IV score first, median (IQR) & $84(64-107)$ & $59(45-81)$ & $<0.0001^{\star \star \star}$ \\
\hline APACHE IV score last, median (IQR) & $74(54-106)$ & $55(41-81)$ & $<0.0001^{\star \star \star}$ \\
\hline SAPS 3 score first, median (IQR) & $48.50(40-57.75)$ & $40(31-49)$ & $<0.0001^{\star \star \star}$ \\
\hline SAPS 3 score last. median (IQR) & $45(37-56)$ & $38(29-47)$ & $<0.0001^{\star \star \star}$ \\
\hline \multicolumn{4}{|l|}{ Vital parameters } \\
\hline HR mean, median (IQR) (1/min) & $96(84-109)$ & $83(72-96)$ & $<0.0001^{\star \star \star}$ \\
\hline NIBP systole mean, median (IQR) (mmHg) & $113(103-126)$ & $118(106-132)$ & $0.0059 * *$ \\
\hline NIBP diastole mean, median (IQR) (mmHg) & $62(55-72)$ & $65(58-72)$ & 0.1043 \\
\hline NIBP mean, median (IQR) (mmHg) & $79(70-87)$ & $82(74-92)$ & $0.0023^{\star *}$ \\
\hline Urine amount, median (IQR) (mL/day) & $500(200-1115)$ & $692(350-1264)$ & $0.0047^{\star \star}$ \\
\hline Body temperature max, median (IQR) (C) & $37(36.2-37.6)$ & $36.6(36.2-37.1)$ & $0.0006^{\star \star \star}$ \\
\hline \multicolumn{4}{|l|}{ Laboratory parameters } \\
\hline Procalcitonin, median (IQR) (ng/mL) & $3.75(0.96-13.82)$ & $0.32(0.16-0.51)$ & $<0.0001^{\star \star \star}$ \\
\hline WBC, median (IQR) $\left(10 \mathrm{e}^{3} / \mathrm{UI}\right)$ & $11.95(7.16-18.03)$ & $11.8(8.3-15.60)$ & 0.9399 \\
\hline CRP, median (IQR) (mg/L) & $0.019(0.008-0.032)$ & $0.003(0.0007-0.010)$ & $<0.0001^{\star \star \star}$ \\
\hline CKMB, median (IQR) (IU/L) & $33.5(21.75-55.25)$ & $29(20-39)$ & 0.0592 \\
\hline PT, median (IQR) (second) & $33.5(21.75-55.25)$ & $29(20-39)$ & $<0.0001^{\star \star \star}$ \\
\hline APTT, median (IQR) (second) & $35.5(30.15-46.7)$ & $26.75(24.1-32.03)$ & $<0.0001^{\star \star \star}$ \\
\hline Urea, median (IQR) (mg/dL) & $60(36-103)$ & $37(25-57)$ & $<0.0001^{\star \star \star}$ \\
\hline Creatinine, median (IQR) (mg/dL) & $1.12(0.68-2.17)$ & $0.79(0.59-1.04)$ & $<0.0001^{\star \star \star}$ \\
\hline Bilirubin, median (IQR) (mg/dL) & $0.66(0.42-1.33)$ & $0.58(0.39-0.89)$ & $0.0146^{\star}$ \\
\hline AST, median (IQR) (IU/L) & $39(22-77)$ & $26(18-44)$ & $<0.0001^{\star \star \star}$ \\
\hline ALT, median (IQR) (IU/L) & $21(12-44)$ & $19(13-33)$ & 0.159 \\
\hline INR, median (IQR) & $1.26(1.11-1.52)$ & $1.08(1.01-1.21)$ & $<0.0001^{\star \star \star}$ \\
\hline Albumin, median (IQR) (g/dL) & $2.6(2.1-3.03)$ & $3.4(2.9-3.8)$ & $<0.0001^{\star \star \star}$ \\
\hline Total protein, median (IQR) (g/dL) & $5.6(4.8-6.2)$ & $6.2(5.6-6.79)$ & $<0.0001^{\star \star *}$ \\
\hline \multicolumn{4}{|c|}{ Student's t-test, Mann-Whitney U, chi-square tests were used. Summary of $p$ values: ${ }^{\star} p<0.05,{ }^{\star \star} p<0.01,{ }^{\star \star \star} p<0.001$, not significant (ns); $p \geq 0.05$} \\
\hline \multicolumn{4}{|c|}{$\begin{array}{l}\text { SOFA score: Sequential organ failure assessment score, APACHE II-IV score: Acute physiology and chronic health evaluation, SAPS: Simplified acute physiology } \\
\text { score, ICU: Intensive care unit, MV: Mechanical ventilation, WBC: White blood cell, CRP: C-reactive protein, AST: Aspartate aminotransferase, ALT: Alanine } \\
\text { aminotransferase, INR: International normalized ratio, NIBP: Non-invasive blood pressure, HR: Heart rate }\end{array}$} \\
\hline
\end{tabular}


IQR values for HDL-C were 20 (10-31) and 29 (15-40) mg/dL, respectively $(p>0.01)$. The median and IQR values for $L D L-C$ were 48 (31-65) and 62 (39-89) mg/dL, respectively ( $p>0.014)$, while those for total cholesterol were 103 (77-123) and 121 (95-159) $\mathrm{mg} / \mathrm{dL}$, respectively ( $>0.002$ ), and their difference was significant. The median and IQR values for triglyceride were 100 (71-200) and 140 (88-190) mg/dL, respectively, and the difference in values was not significant $(p=0.4)$.

In the comparison of surgical $(33 \%, n=50)$ and medical $(67 \%$, $\mathrm{n}=101)$ subgroups of patients with sepsis, the median and IQR values for HDL-C were 18 (8-30) and 29 (14-39) mg/ $\mathrm{dL}$, respectively $(p>0.003)$, those for $L D L-C$ were 44 (31-61) and $62(41-84) \mathrm{mg} / \mathrm{dL}$, respectively $(p>0.0008)$, and those for total cholesterol were 98 (73-130) and 120 (96-150) mg/ $d L$, respectively $(p>0.0007)$, and their differences were significant. The median and IQR values for triglyceride were $110(71-200)$ and $130(86-190) \mathrm{mg} / \mathrm{dL}$, respectively, but the difference was not significant $(p=0.3)$.

In the comparison of gram-negative $(25 \%, n=39)$ and grampositive $(23 \%, n=35)$, subgroups, the median and IQR values for HDL-C were 23 (14-36) and 35 (28-44) mg/dL, respectively, and the difference was significant $(p=0.025)$. The median and IQR values were 65 (36-87) and $69(42-91) \mathrm{mg} / \mathrm{dL}(p=0.5)$ for LDL-C, 120 (66-150) and $130(100-160) \mathrm{mg} / \mathrm{dL}(p=0.8)$ for total cholesterol, and 90 (63-169) and 127 (86-185) mg/dL $(p=0.19)$, for triglyceride, respectively, and their differences were not significant.

In the similar analysis for culture-positive $(48 \%, n=73)$ and culture-negative $(44 \%, n=67)$ subgroups, the median and IQR values for HDL-C were 30 (17-40) and 19 (9-32) mg/dL, respectively $(p=0.006)$, and the difference was significant. The median and IQR values were 65 (41-90) and 53 (33-72) $\mathrm{mg} / \mathrm{dL}(\mathrm{p}=0.037)$ for LDL-C, 120 (87-150) and 110 (82-140) $\mathrm{mg} / \mathrm{dL}(\mathrm{p}=0.14)$ for total cholesterol, and 100 (68-185) and 138 (88-203) mg/dL ( $p=0.051)$ for triglyceride, respectively, and the differences were not significant.

When the ICU admission procalcitonin values of sepsis subgroups were analyzed with the Mann-Whitney $U$ test, the median and IQR values of the intra-abdominal sepsis and pneumosepsis subgroups were $6.1(1.2-33.8)$ and 2.4 $(0.4-8.8) \mathrm{mg} / \mathrm{dL}$, respectively $(p=0.045)$. The median and IQR values of the surgical and medical subgroups were 7.5 (1.4-27.4) and $2.3(0.5-8.2) \mathrm{mg} / \mathrm{dL}$, respectively $(p=0.02)$. The median and IQR values of the gram-negative and grampositive subgroups were $3.4(0.6-13)$ and $1.5(0.4-6.5) \mathrm{mg} /$ $\mathrm{dL}$, respectively $(p=0.18)$; the values for culture-positive and culture-negative subgroups were $2.2(0.5-7.9)$ and 3.5 (1.0-14.3) $\mathrm{mg} / \mathrm{dL}$, respectively, and a significant difference was determined only in the comparison of the surgical and medical subgroups $(p=0.18)$.
In the survival non-survival analysis made according to the duration of ICU stay of patients with sepsis $(n=151)$ and without sepsis $(n=451)$, the median survival values were 9 and 2 days, and the medial ratio was 4.5 with $95 \% \mathrm{Cl}$ of 3.697-5.303. The hazard ratio was 0.9284 , with $95 \% \mathrm{Cl}$ of $0.6108-1.411$, and the values were considered significant $(p<0.0001)$

In the sepsis group, when the survivor $(n=61)$ and nonsurvivor $(n=51)$ subgroups were compared, the median and IQR values for HDL-C were 28 (15-35) and 26 (9-38) mg/dL, respectively, and the difference was not significant $(p=0.9)$. The values obtained from the survivor-non-survivor analyses for LDL-C, total cholesterol, and triglyceride were not significant.

\section{DISCUSSION}

Adequate levels of HDL-C and LDL-C are thought to be protective against sepsis. LDL-C facilitates bacterial toxin clearance via hepatic LDL receptors or HDL-C. Bacterial toxin binding, inhibition of inflammatory cytokine release, inhibition of vascular and intercellular adhesion molecule expression, and stimulation of endogenous corticosteroid secretion have been reported as prevention mechanisms of HDL-C-associated sepsis (17).

HDL particles have been shown to protect endothelial cells by reducing leukocyte extravasation in inflammation $(18,19)$. $\mathrm{HDL}$ is a protective factor in sepsis because of its antioxidant effects. HDL-C can increase nitric oxide production of endothelial cells, and HDLs can bind to enzymes such as paraoxonase-1 or platelet-activating factor acetylhydrosis, which exhibits antioxidant and endothelial protective properties. The positive effects of HDLs on cleansing liposaccharides of microorganisms from tissues and organs were shown in a previous study (20).

In vivo studies have shown that LPS interacts very early with HDL within 3 min of intravenous administration and remains associated with HDL until clearance. However, a new study on human lipoprotein fractions showed the absence of LPS detoxification activity in the serum. In addition, some HDL apoproteins may function as coenzymes of LPS-inactivating enzymes different from arylesterase. A coenzyme function of apoprotein A-I and C-II was described in lipid metabolism (21). Further, only binding of LPS to HDL can determine the biological effect and in vivo distribution of LPS and facilitate or delay the internalization into phagocytic system cells. More work is ongoing on the biological significance of HDLLPS interaction.

In this study, the initial lipoprotein values (HDL-C, LDL-C, and total cholesterol) of patients who were taken to the ICU 
in the last 6 years because of sepsis and serum lipoprotein values of patients without sepsis were compared. The lipoprotein levels of patients with sepsis were significantly lower than those of patients without sepsis (Figure 1A, B, C). In a previous study, HDL-C levels were found to decrease rapidly in the early stage of sepsis development (17). Tanaka et al. (22) compared patients with sepsis and those with trauma and found that HDL-C levels were lower in those with sepsis. Another study of patients who underwent cardiac surgery reported lower preoperative cholesterol levels in the sepsis group $(23,24)$.

In the subgroup analyses of patients with sepsis, the HDL-C values were significantly lower and the procalcitonin values were higher in the intra-abdominal, surgical, and gram-negative subgroups. This was thought to be due to the source control of patients with intra-abdominal sepsis required surgery, which was brought under control lately. Interestingly, although no significant difference was found between the procalcitonin values of the culturepositive and culture-negative groups, their HDL-C levels were significantly low. The suspicion of anaerobic infection should also be taken into consideration because $45 \%$ of patients with negative cultures were those with intraabdominal sepsis and a routine anaerobic culture test was not performed in the center where the study was conducted (Table 2). Barlage et al. (25) suggested that the beneficial effects of HDLs on gram-positive infections may result from other anti-inflammatory properties, including modulation of neutrophil activation.

Several studies have reported a relationship between HDL-C and morbidity/mortality. The total cholesterol, HDL-C, and LDL-C values were significantly lower in the non-survivor group than in the survivor group (8). However, in the present study, no significant difference was found in the serum HDL-C, LDL-C, total cholesterol, and triglyceride levels of patients with sepsis who were discharged from the ICU and deceased patients. These findings suggest that serum lipoprotein levels may affect the development of infection-induced sepsis. Similarly, although the findings of the present study support the pathological mechanism that serum lipoproteins may play a role in endotoxin neutralization, it does not support the "abnormal host response" to infection highlighted in the definition of sepsis, or, in other words, the role of serum HDL-C levels in host immune dysregulation emphasized in the "current sepsis guideline," which is the current consensus (2).

Chien et al. (8) observed significant increases in the sepsisassociated 30-day mortality, overall mortality, risk of prolonged ICU stay, and hospital-acquired infection rate in patients with sepsis with $\mathrm{HDL}-\mathrm{C}<20 \mathrm{mg} / \mathrm{dL}$.

In the light of these publications showing the protective effect of cholesterol on sepsis, studies are ongoing to determine the effect of lipid emulsions on the clinical outcome by stabilizing cholesterol levels early in sepsis. Although sepsis is not included in the treatment guideline, many researchers recommend that HDL be given to patients with severe sepsis and septic shock based on the results of studies supporting the suggestion that the restoration of the physiological immunomodulatory activity of HDL may provide a new therapeutic opportunity for sepsis (23).

In a Mendelian randomization study, the authors found significant reductions in HDL-C concentrations during sepsis in individuals with cholesteryl ester transfer proteinrs1800777 missense variant and associated the reductions with increased mortality and morbidity (26).

\section{CONCLUSION}

This study highlights the important role of serum lipoproteins in the neutralization of endotoxins at the onset of sepsis. The subgroup analysis revealed a significant decrease in the HDL-C level in patients with sepsis, which suggests that serum HDL-C level has immunomodulatory properties as well as endotoxin-neutralizing function.

Table 2. Characteristics and numerical distribution of microorganisms in the culture-positive and culture-negative subgroups among patients with sepsis

\begin{tabular}{|c|c|c|c|c|c|c|c|c|}
\hline \multirow[b]{2}{*}{ Microorganisms cultured, $n=148$} & \multicolumn{2}{|c|}{$\begin{array}{l}\text { Abdominal sepsis } \\
\mathrm{n}=49\end{array}$} & \multicolumn{2}{|c|}{$\begin{array}{l}\text { Pneumosepsis } \\
\mathrm{n}=69\end{array}$} & \multicolumn{2}{|c|}{$\begin{array}{l}\text { Urosepsis } \\
n=10\end{array}$} & \multicolumn{2}{|c|}{$\begin{array}{l}\text { Other sepsis } \\
\text { (fasit, meningitis, etc.) } \\
n=20\end{array}$} \\
\hline & Medical & Surgical & Medical & Surgical & Medical & Surgical & Medical & Surgical \\
\hline Gram-negative, $n=36$ & 3 & 8 & 18 & 0 & 2 & 0 & 5 & 0 \\
\hline Gram-positive, $n=35$ & 2 & 2 & 22 & 1 & 2 & 1 & 4 & 1 \\
\hline Fungus, $n=10$ & 0 & 4 & 2 & 1 & 1 & 1 & 1 & 0 \\
\hline Culture-negative, $n=67$ & 7 & 23 & 25 & 0 & 2 & 1 & 7 & 2 \\
\hline
\end{tabular}




\section{ETHICS}

Ethics Committee Approval: The present study was approved by the Bakırköy Dr. Sadi Konuk Training and Research Hospital, Clinical Research Ethics Committee of the public hospital where the study was conducted, with the decision dated 14.10.2019 and no: 2019/459.

Informed Consent: Retrospective study.

Acknowledgment: We would like to thank Okan Gürler and Fuat Tuna for their help in data collection.

\section{Authorship Contributions}

Surgical and Medical Practices: S.A., M.S.S., E.K.T., Ö.A., Z.Ç., Concept: S.A., M.S.S., E.K.T., Ö.A., Z.Ç., Design: S.A., M.S.S., E.K.T., Ö.A., Z.C.., Data Collection or Processing: S.A., M.S.S., E.K.T., Ö.A., Z.Ç., Analysis or Interpretation: S.A., M.S.S., E.K.T., Ö.A., Z.Ç., Literature Search: S.A., M.S.S., E.K.T., Ö.A., Z.Ç., Writing: S.A., M.S.S., E.K.T., Ö.A., Z.Ç.

Conflict of Interest: No conflict of interest was declared by the authors.

Financial Disclosure: The authors declared that this study received no financial support.

\section{REFERENCES}

1. Fleischmann C, Scherag A, Adhikari NK, Hartog CS, Tsaganos T, Schlattmann P, et al. Assessment of Global Incidence and Mortality of Hospital-treated Sepsis. Current Estimates and Limitations. Am J Respir Crit Care Med 2016;193:259-72.

2. Angus DC, van der Poll T. Severe sepsis and septic shock. N Engl J Med 2013;369:840-51.

3. Jones TK, Wong HR, Meyer NJ. HDL Cholesterol: A "Pathogen Lipid Sink" for Sepsis? Am J Respir Crit Care Med 2019;199:812-4.

4. Khovidhunkit W, Kim MS, Memon RA, Shigenaga JK, Moser AH Feingold KR, et al. Effects of infection and inflammation on lipid and lipoprotein metabolism: mechanisms and consequences to the host. J Lipid Res 2004;45:1169-96.

5. Eckardstein AV. HDL in infectious disease and sepsis. In: Eckardstein AV, Kardassis D, eds. Handbook of Experimental Pharmacology. 224 th ed. Springer; 2015:483-508.

6. Boyd JH, Fjell CD, Russell JA, Sirounis D, Cirstea MS, Walley KR Increased Plasma PCSK9 Levels Are Associated with Reduced Endotoxin Clearance and the Development of Acute Organ Failures during Sepsis. J Innate Immun 2016;8:211-20.

7. Guirgis FW, Dodani S, Moldawer L, Leeuwenburgh C, Bowman J, Kalynych $\mathrm{C}$, et al. Exploring the Predictive Ability of Dysfunctional High-Density Lipoprotein for Adverse Outcomes in Emergency Department Patients with Sepsis: A Preliminary Investigation. Shock 2017:48:539-44.

8. Chien JY, Jerng JS, Yu CJ, Yang PC. Low serum level of high-density lipoprotein cholesterol is a poor prognostic factor for severe sepsis. Crit Care Med 2005;33:1688-93.

9. Grion CM, Cardoso LT, Perazolo TF, Garcia AS, Barbosa DS, Morimoto HK, et al. Lipoproteins and CETP levels as risk factors for severe sepsis in hospitalized patients. Eur J Clin Invest 2010;40:3308.
10. Chien YF, Chen CY, Hsu CL, Chen KY, Yu CJ. Decreased serum level of lipoprotein cholesterol is a poor prognostic factor for patients with severe community-acquired pneumonia that required intensive care unit admission. J Crit Care 2015;30:506-10.

11. Iribarren C, Jacobs DR Jr, Sidney S, Claxton AJ, Feingold KR. Cohort study of serum total cholesterol and in-hospital incidence of infectious diseases. Epidemiol Infect 1998;121:335-47.

12. Schatz IJ, Masaki K, Yano K, Chen R, Rodriguez BL, Curb JD. Cholesterol and all-cause mortality in elderly people from the Honolulu Heart Program: a cohort study. Lancet 2001;358:351-5.

13. Gordon BR, Parker TS, Levine DM, Saal SD, Wang JC, Sloan BJ, et al. Low lipid concentrations in critical illness: implications for preventing and treating endotoxemia. Crit Care Med 1996;24:5849.

14. Gordon BR, Parker TS, Levine DM, Saal SD, Wang JC, Sloan BJ, et al. Relationship of hypolipidemia to cytokine concentrations and outcomes in critically ill surgical patients. Crit Care Med 2001;29:1563-8

15. Dellinger RP, Levy MM, Rhodes A, Annane D, Gerlach H, Opal $S M$, et al. Surviving Sepsis Campaign: international guidelines for management of severe sepsis and septic shock, 2012. Intensive Care Med 2013;39:165-228

16. Story DA, Morimatsu H, Bellomo R. Strong ions, weak acids and base excess: a simplified Fencl-Stewart approach to clinical acidbase disorders. Br J Anaesth 2004:92:54-60.

17. van Leeuwen HJ, Heezius EC, Dallinga GM, van Strijp JA, Verhoef $J$, van Kessel KP. Lipoprotein metabolism in patients with severe sepsis. Crit Care Med 200;31:1359-66.

18. McDonald MC, Dhadly P, Cockerill GW, Cuzzocrea S, Mota-Filipe H, Hinds CJ, et al. Reconstituted high-density lipoprotein attenuates organ injury and adhesion molecule expression in a rodent model of endotoxic shock. Shock 2003;20:551-7.

19. Murch O, Collin M, Hinds CJ, Thiemermann C. Lipoproteins in inflammation and sepsis. I. Basic science. Intensive Care Med 2007;33:13-24.

20. Pajkrt D, Doran JE, Koster F, Lerch PG, Arnet B, van der Poll T, et al. Antiinflammatory effects of reconstituted high-density lipoprotein during human endotoxemia. J Exp Med 1996;184:1601-8.

21. Freudenberg MA, Bøg-Hansen TC, Back U, Galanos C. Interaction of lipopolysaccharides with plasma high-density lipoprotein in rats. Infect Immun 1980;28:373-80.

22. Tanaka S, Labreuche J, Drumez E, Harrois A, Hamada S, Vigué B, et al. Low HDL levels in sepsis versus trauma patients in intensive care unit. Ann Intensive Care 2017;7:60.

23. Guirgis FW, Black LP, Rosenthal MD, Henson M, Ferreira J,

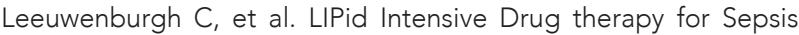
Pilot (LIPIDS-P): Phase I/II clinical trial protocol of lipid emulsion therapy for stabilising cholesterol levels in sepsis and septic shock. BMJ Open 2019;9:029348

24. Lagrost L, Girard C, Grosjean S, Masson D, Deckert V, Gautier T, et al. Low preoperative cholesterol level is a risk factor of sepsis and poor clinical outcome in patients undergoing cardiac surgery with cardiopulmonary bypass. Crit Care Med 2014;42:1065-73.

25. Barlage S, Gnewuch C, Liebisch G, WolfZ, Audebert FX, Glück T, et al. Changes in HDL-associated apolipoproteins relate to mortality in human sepsis and correlate to monocyte and platelet activation. Intensive Care Med 2009;35:1877-85.

26. Trinder M, Genga KR, Kong HJ, Blauw LL, Lo C, Li X, et al. Cholesteryl Ester Transfer Protein Influences High-Density Lipoprotein Levels and Survival in Sepsis. Am J Respir Crit Care Med 2019;199:854-62. 